\title{
SPEKTRUM SUARA GULAMAH SEBAGAI KAJIAN AWAL PEMBUATAN RUMPON: KASUS DI PERAIRAN TUBAN, JAWA TIMUR
}

\section{SPECTRUM SOUND OF GULAMAH AS A PRELIMINARY STUDY DEVELOPMENT SOUND-FISH AGGREGATING DEVICE: CASE IN TUBAN WATERS, EAST JAVA}

\author{
Eko Sulkhani Yulianto ${ }^{1,2}$, Alfan Jauhari ${ }^{1,2}$, Dewa Gedhe Raka Wiadnya ${ }^{1,3}$, Sunardi ${ }^{1,2}$, Muhammad Arif Rahman $^{1,4}$ \\ ${ }^{1}$ Pemanfaatan Sumberdaya Perikanan, Fakultas Perikanan dan Ilmu Kelautan, Universitas Brawijaya Malang \\ ${ }^{2}$ Indonesian Marine Fisheries Research Group, Brawijaya University \\ ${ }^{3}$ Bioflock Research Group, Brawijaya University \\ ${ }^{4}$ Marine Exploration and Management Research Group, Brawijaya University \\ Korespondensi: ekosulkhaniy@ub.ac.id
}

\begin{abstract}
One of the leading commodities in the North Coast of East Java which has a large production is gulamah (Sciaenidae). This fish is one of the marine fisheries commodities that have high potential. Previously the use of gulamah was limited to fresh fish and dried fish. Lately these organs in fish (swimming bladders) have also been widely used and actually have much higher economic value. The high economic value of these commodities has implications for the increasing pressure on exploitation of these fish. In fact, sometimes arrests are made without regard to responsible fishing rules. Gulamah is one type of fish that often makes a "croak" sound in its behavioral activities. Study of the schooling sound spectrum of gulamah (Sciaenidae) as a preliminary study for the manufacture of effective and environmentally friendly Sound-Fish Aggreagating Device as one of the food security instruments for marine fisheries products. So it is expected that with the introduction of new technologies that are efficient, effective, simple and can provide economic added value for fishermen. Analytical descriptive research method and experimental fishing, the data collected is the sound spectrum data schooling gulamah (Sciaenidae), where data collection is carried out at Tombokboyo Waters, Tuban, East Java. The results showed that gulamah in Tombokboyo waters issued a sound with an average amplitude of around $-54,97 \mathrm{~dB}$, an average frequency of 732,129 Hz, with a sound duration of 130 miliseconds.
\end{abstract}

Keyword: frequency, gulamah, sound spectrum, Tuban

\begin{abstract}
ABSTRAK
Salah satu komoditas unggulan di Pantai Utara Jawa Timur yang memiliki produksi cukup besar adalah ikan gulamah (Sciaenidae). Ikan ini merupakan salah satu komoditas perikanan laut yang mempunyai potensi tinggi. Sebelumnya pemanfaatan ikan gulamah hanya sebatas dalam bentuk ikan segar dan ikan asing/kering. Belakangan ini organ dalam ikan ini (gelembung renang) juga banyak dimanfaatkan dan justru mempunyai nilai ekonomis jauh lebih tinggi. Tingginya nilai ekonomis pada komoditas ini berimplikasi meningkatnya tekanan eksploitasi terhadap ikan ini semakin meningkat. Bahkan terkadang upaya penangkapan yang dilakukan tanpa memperhatikan kaidah-kaidah penangkapan yang bertanggungjawab. Gulamah merupakan salah satu jenis ikan yang sering mengeluarkan suara "croak" dalam aktivitas tingkah lakunya. Kajian tentang spektrum suara schooling ikan gulamah/tigawaja sebagai kajian awal pembuatan alat pendeteksi dan pengumpul ikan berbasis suara yang efektif dan ramah lingkungan sebagai salah satu instrumen ketahanan pangan produk perikanan laut. Sehingga diharapkan dengan adanya introduksi teknologi baru yang efisien, efektif, murah, sederhana dan dapat memberikan nilai tambah ekonomi bagi nelayan. Metode penelitian deskriptif analitik dan experimental fishing, data yang dikumpulkan adalah data spektrum suara schooling ikan gulamah (Sciaenidae), dimana pengambilan data dilakukan di Perairan Tombokboyo, Tuban, Jawa Timur. Hasil penelitian menunjukkan bahwa ikan gulamah di Perairan Tombokboyo mengeluarkan suara dengan rata-rata amplitude berkisar - 54,97 dB, ratarata frekuensi 732,129 Hz, dengan durasi suara 130 miliseconds.
\end{abstract}

Kata kunci: frekuensi, gulamah, spektrum suara, Tuban 


\section{PENDAHULUAN}

Salah satu komoditas unggulan di Pantai Utara Jawa Timur yang memiliki produksi cukup besar adalah ikan gulamah (Sciaenidae). Ikan dari family Sciaenidae ini merupakan salah satu komoditas perikanan laut yang mempunyai potensi tinggi. Jika sebelumnya pemanfaatan ikan gulamah hanya sebatas dalam bentuk ikan segar dan ikan asing/kering. Belakangan ini organ dalam ikan ini yaitu gelembung renangnya juga banyak dimanfaatkan dan justru mempunyai nilai ekonomis yang jauh lebih tinggi. Seperti yang dilansir dalam Imrantika (2018), di beberapa negara Asia Timur seperti negara Jepang, Korea Cina, serta beberapa negara Asia Tenggara seperti Thailand dan Filipina yang telah mengolah gelembung renang ikan menjadi makanan mewah dengan harga tinggi yang dikenal dengan sebutan fish maw. Selain itu gelembung renang ini juga sudah mulai dimanfaatkan dalam dunia medis. Organ ini dipakai sebagai benang jahit pasca operasi atau luka karena teksturnya yang tipis, lentur, dan kuat (Hanna 2017).

Tingginya nilai ekonomis pada komoditas ini berimplikasi meningkatnya tekanan eksploitasi terhadap jenis ikan ini yang semakin pesat. Bahkan terkadang untuk memenuhi kebutuhan pasar tersebut, seringkali upaya penangkapan ikan dilakukan tanpa memperhatikan kaidah-kaidah penangkapan ikan yang bertanggungjawab, seperti kegiatan penangkapan tanpa mengindahkan sumber daya ikan ukuran layak tangkap Nelayan Jawa Timur yang biasa menangkap ikan gulamah, memanfaatkan pola tingkah laku/ kebiasaan dari ikan ini yaitu mengeluarkan suara ketika sedang beraktivitas bergerombol dengan mengeluarkan bunyi "tetet", sehingga sebagian nelayan Indonesia menyebut ikan gulamah dengan ikan tetet. Ikan gulamah ini, merupakan salah satu jenis ikan yang mengeluarkan suara seperti yang dikemukakan Fish dan Mowbray (1970); Juanes (2002); Kaatz (2002); Johnston dan Phillips (2003); Johnston dan Vives (2003); Rountree et al. (2006), bahwa terdapat lebih dari 700 spesies ikan dari sekurang-kurangnya 30 famili yang diketahui memproduksi suara. Produksi suara ini berpotensi untuk dideteksi dengan metode akustik pasif. Akustik pasif identik dengan penggunaan alat perekam suara bawah air yang sering disebut dengan hydrophone.
Nelayan Tuban tidak akan menebarkan jaring/gillnet nya, sebelum sang fishing master merasa yakin akan keberadaan ikan. Perilaku intuitif mendengarkan suara ikan tidak dimiliki semua nelayan, hal ini akan berdampak pada eksistensi dan keberlanjutan kegiatan penangkapan apabila tidak ada generasi penerus yang menguasainya. Selain itu, penyelaman tanpa alat yang dilakukan oleh nelayan yang berlangsung lama dan terusmenerus tanpa disadari akan berpengaruh terhadap kesehatan, dan cenderung membahayakan. Dengan diketahuinya spektrum suara gulamah memungkinkan pengembangan alat pengumpul gulamah (FAD) berbasis suara. Gagasan ini didasakan bahwa ikan-ikan mengeluarkan suara sebagai interaksi komunitas, reaksi terhadap lawan jenis dan sebagainya (Lubis et al. 2015). Gagasan ini juga di perkuat dari beberapa kajian diantaranya Yusfiandayani et al. (2014), menguji rumpon elektronik dengan atraktor berupa cahaya (LED, 5 Watt) dan suara (10-1000 Hz, 1-20 kHz dan 20-100 kHz) berhasil mengumpulkan ratarata $4,60 \mathrm{~kg}$ untuk waktu pemasangan satu jam, dan rata-rata 4,07 kg untuk lama waktu pemasangan setengah jam. Pada tahun yang sama, menguji EFA (Electric Fish Atractor) pada frekuensi $10-1000 \mathrm{~Hz}$ mendapatkan ikan kuwe (Caranx fasciatus) dan ikan layur hitam (Trichiurus sp.), sedangkan EFA dengan frekuensi 1000-20.000 Hz mendapatkan ikan tuna sirip kuning, Thunnus albacares (Yusfiandayani et al. 2014). Penelitian lain mengungkapkan bahwa electric fish atractor menggunakan frekuensi suara sebesar 1.000-5.000 Hz, 6.000-10.000 Hz, 11.000$15.000 \mathrm{~Hz}$ dikombinasikan 3 unit pancing ulur mendapatkan hasil tangkapan berupa tongkol (Euthynnus affinis), kembung (Rastrelliger branchysoma), ikan todak (Xiphias gladius), barakuda (Sphyraena baracuda), dan ikan ekor kuning (Caesio cuning) (Yusfiandayani et al. 2018). Berdasarkan hal tersebut, dapat disimpulkan bahwa ikan dapat tertarik dengan adanya suara/bunyi. Namun permasalahannya, selama ini belum dilakukan kajian mengenai spektrum suara schooling ikan gulamah/ tigawaja khususnya di Pantura Jawa Timur. Melalui metode penelitian akustik pasif ini diharapkan diperoleh kisaran frekuensi dan amplitude dari schooling ikan gulamah (Scianidae) sehingga bisa dijadikan referensi dalam pengembangan FAD (Fish Aggregating Device) berbasis suara. 


\section{METODE PENELITIAN}

Metode penelitian yang digunakan dalam kegiatan penelitian ini adalah dengan menggunakan metode penelitian deskriptif analitik. Penelitian ini akan menghasilkan sebaran spektrum suara Metode penelitian yang digunakan dalam kegiatan penelitian ini adalah dengan menggunakan metode penelitian deskriptif analitik. Penelitian ini akan menghasilkan sebaran spektrum suara schooling ikan gulamah sehingga dapat dijadikan acuan dalam pembuatan $S-F A D$ yang ramah lingkungan. Penggunaan suara untuk mendeteksi sumberdaya ikan atau sering akustik perikanan terdiri dari dua pembagian utama yaitu akustik aktif dan pasif (Randhi et al. 2017), dalam penelitian ini untuk memperoleh suara schooling ikan akan dilakukan perekaman dengan menggunakan hydrophone pada saat bersamaan nelayan mendeteksi schooling ikan tersebut.

Pengambilan data spektrum dilakukan dua tahap Pengambilan data spektrum dilakukan dua tahap, tahap pertama dilakukan pada bulan September 2018 dan tahap kedua dilakukan pada bulan Oktober 2018. Proses perekaman dilakukan setelah nelayan selesai setting encircling gillnet nya, sehingga yang direkam merupakan ikan-ikan sudah terkurung. Peneliti memastikan bahwa suara spektrum ikan yang direkam merupakan schooling ikan gulamah berdasarkan keahlian dan kebiasaan nelayan. Beberapa nelayan Tuban mempunyai keahlian untuk mendengarkan suara ikan dalam air (Gambar 1), sebelum gillnet tersebut dioperasikan nelayan terlebih dahulu mencari gerombolan ikan dengan cara snorkeling barulah setelah menemukan gerombolan ikan alat tangkap tersebut dioperasikan.

Proses perekaman dilakukan dengan alat recording yang dihubungkan ke hydrophone dan disimpan dalam format audio (wav). Selanjutnya proses pengolahan dilakukan dengan software audio. Secara rinci alur penelitian disampaikan pada Gambar 2 .

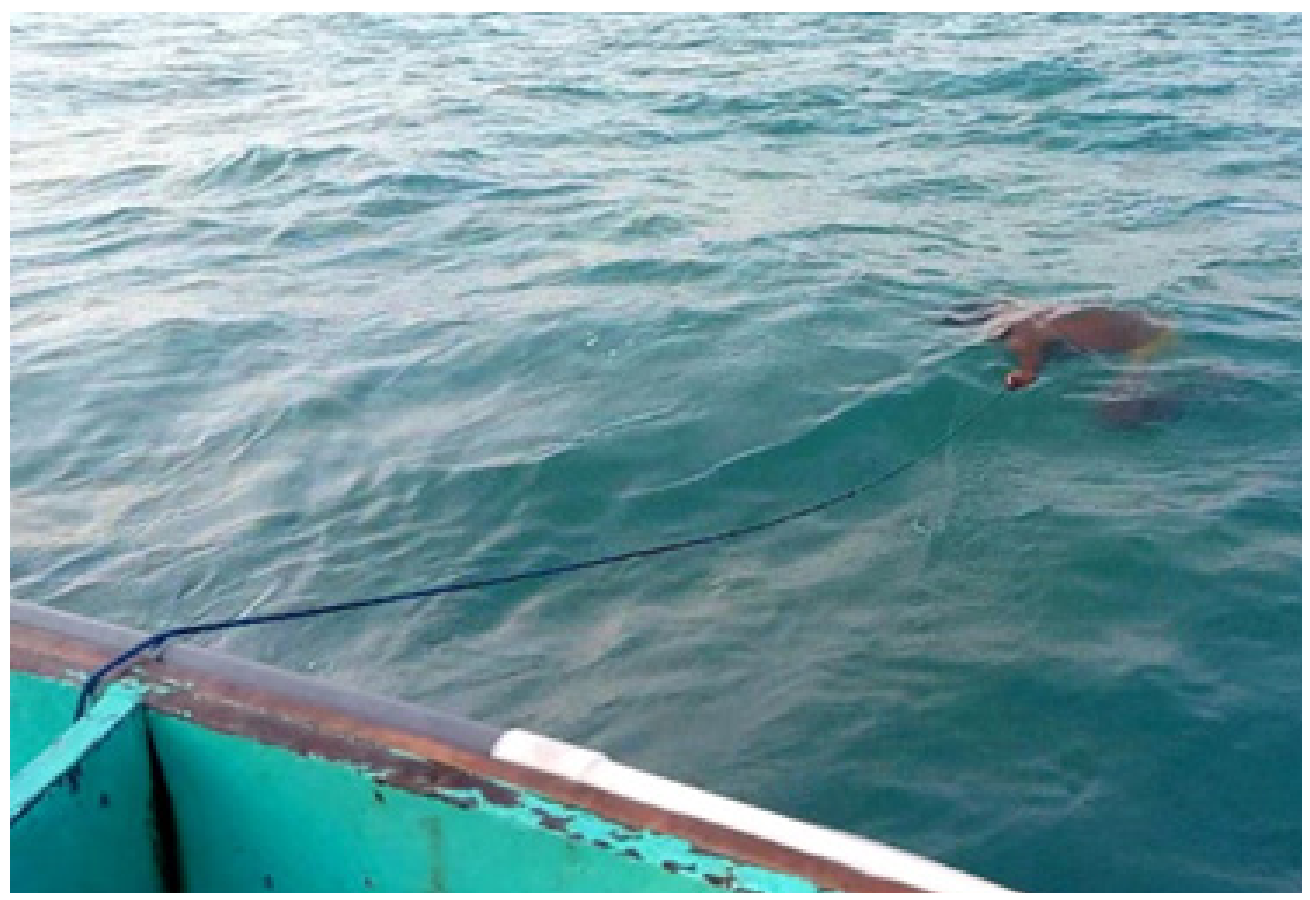

Gambar 1. Proses pencarian schooling ikan gulamah oleh nelayan Tuban 


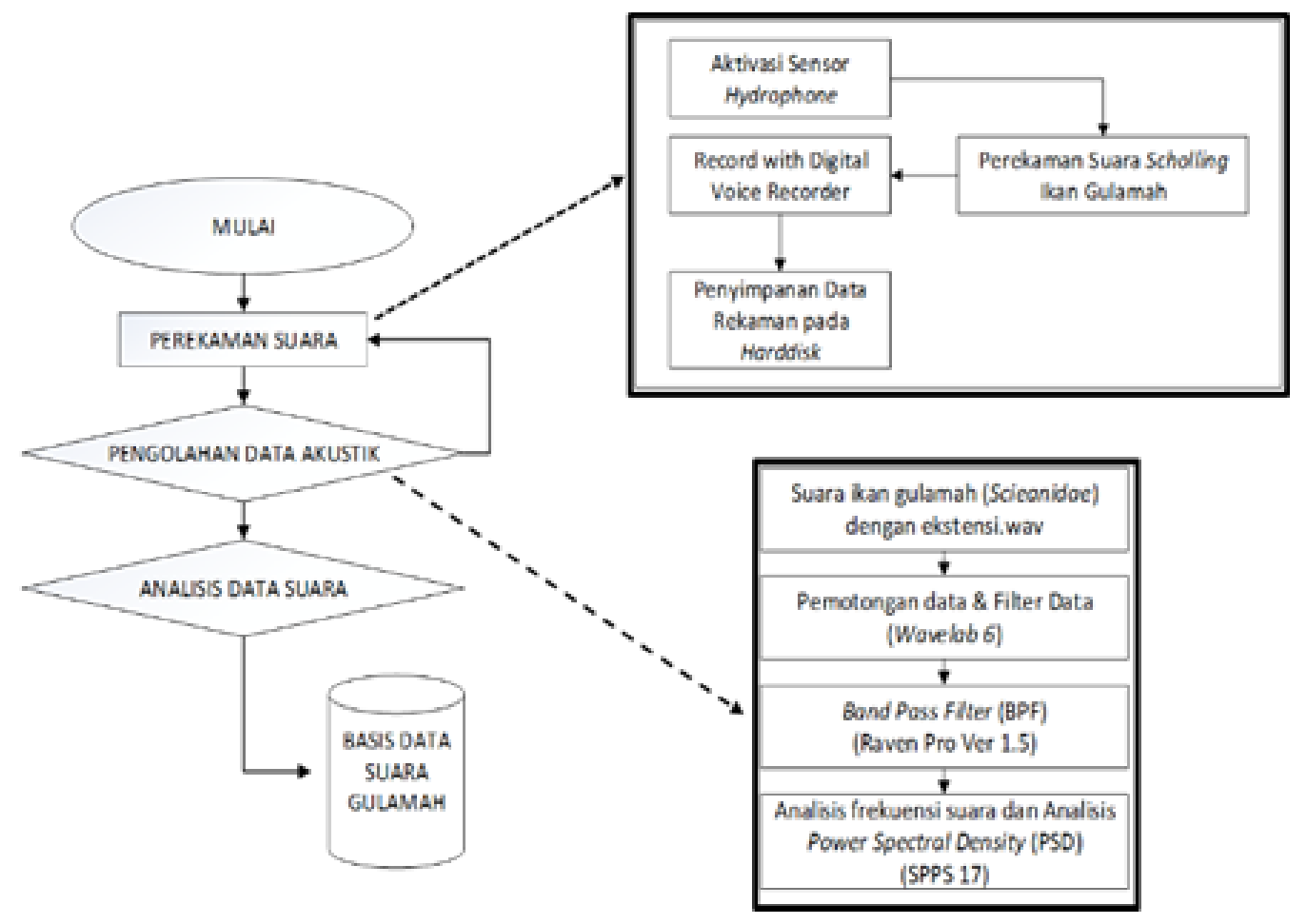

Gambar 2. Alur penelitian

\section{HASIL DAN PEMBAHASAN}

Ikan jenis croakers merupakan jenis ikan yang biasa mengeluarkan suara ikan, dimana suara-suara ini muncul secara alami yang berasal dari otot-otot sekitar gelembung renang. Adanya gelembung renang menambah tingkat kekerasan dari suara yang dihasilkan, karena gelembung renang adalah ruangan kosong sehingga dapat dikatakan sebagai ruang resonansi. Menurut Kottelat et al. (1993), suara-suara ini keluar secara alami dan khususnya pada musim berkembang biak. Hal ini juga selaras dengan pendapat Lugli et al. (2003); Lubis et al. (2015) mengenai ikan Padogobius martensii yang mengeluarkan suara saat berinteraksi dengan lawan jenis yang dihasilkan oleh gelembung renang.

Begitupula dengan ikan gulamah (Johnius trachycephalus) merupakan ikan dari family Sciaenidae yang sering mengeluarkan suara dalam aktivitasnya. Suara yang dihasilkan berasal dari otototot sekitar gelembung renangnya, ruang resonansi (gelembung renang) memperjelas atau meningkatkan suaranya sehingga suara dapat dengan jelas terdengar dengan telinga telanjang.
Selain suara yang dihasilkan oleh otot-otot sekitar gelembung renang, ada juga jenis ikan yang mengeluarkan suara, dimana suara yang dihasilkan adalah dari gerakkan bagian-bagian tubuh, misalnya: sirip, gigi, dan bagian tubuh lainnya yang keras (Walker 1997; Pitcher 1993). Suara jenis ini sering disebut dengan suara stridulatory. Menurut Winn (1991), Ikan bertulang keras (teleost) memiliki suara yang dihasilkan dari kepakan sirip dan beberapa jenis suara stridulatory lainnya memiliki amplitudo besar, yang tersebar secara seragam diseluruh frekuensi. Frekuensi kepakan sirip mencapai lebih dari $6.000 \mathrm{~Hz}$.

Hasil penelitian menunjukkan bahwa ikan gulamah di Perairan Tombokboyo, Kabupaten Tuban mengeluarkan suara dengan didominasi amplitude suara sekitar $-54,97 \mathrm{~dB}$, dominasi frekuensi 732,129 $\mathrm{Hz}$, dengan rata-rata selang suara 130 miliseconds. Seperti yang ditunjukkan pada Tabel 1. Kisaran selang suara tersebut yang dihasilkan lebih besar jika dibandingkan dengan spesies Atlantic sroaker dengan durasi bunyi rata-rata adalah $97 \mathrm{msec}$ (Damon 2007). Dokumentasi ikan gulamah hasil penelitian dapat dilihat pada Gambar 3. 
Tabel 1. Dominasi frekuensi dan amplitude ikan gulamah, serta total power dan rata-rata selang suara

\begin{tabular}{clcc}
\hline No & Parameter & Nilai & Satuan \\
\hline 1 & Frekuensi & 732,129 & $\mathrm{~Hz}$ \\
2 & Peak Amplitude & $-54,97$ & $\mathrm{~dB}$ \\
3 & Total Power & $-41,75$ & $\mathrm{~dB}$ \\
4 & Selang Suara & 130 & miliseconds \\
\hline
\end{tabular}

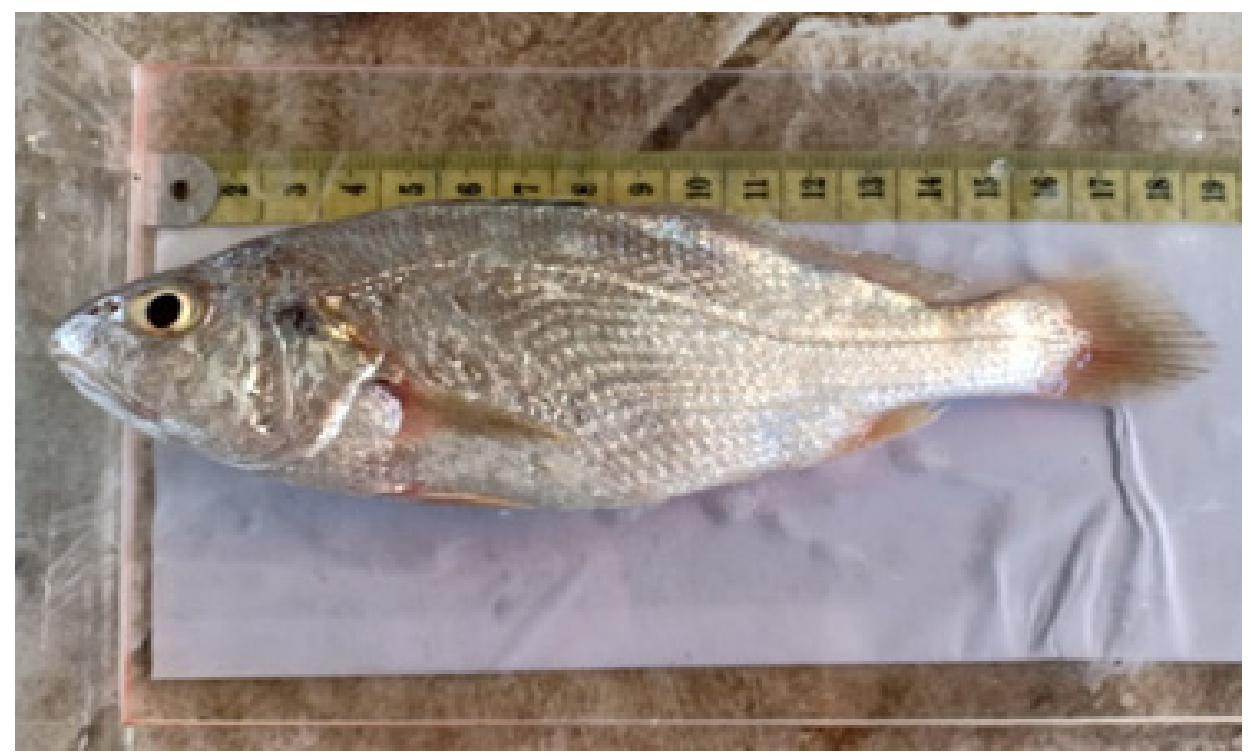

Gambar 3. Dokumentasi ikan gulamah hasil penelitian

Hubungan antara frekuensi $(\mathrm{Hz})$ dan relatif amplitude suara selama periode waktu disajikan pada Gambar 4 (sumbu y kiri) dan Gambar 4 (sumbu x). Secara detail selang frekuensi yang terdeteksi pada $37,83 \mathrm{~Hz}-$ $1795 \mathrm{~Hz}$ dengan peak frekuensi 732,13 Hz. Hal ini tidak berbeda jauh dengan frekuensi ikan yellow croaker (Pseudosciaena crocea) yang dieliti oleh Xin-min et al. (2007) dimana peak frekuensi dari ikan tersebut adalah $800 \mathrm{~Hz}$. Martin dan Amundsen (2011) juga mengemukakan sejumlah kecil spesies dapat mendeteksi suara hingga lebih dari $3.000 \mathrm{~Hz}$, sementara sangat sedikit yang bisa mendeteksi suara hingga lebih dari 100 $\mathrm{kHz}$. Salah satu faktor yang mempengaruhi rendah tingginya frekuensi suara adalah umur ikan, semakin dewasa umur ikan frekuensi semakin rendah. Nilai rata-rata frekuensi yellow croakers (Pseudosciaena croce) pada kelompok ikan berusia 7-8 bulan berkisar 1311,2 Hz-1036,8 Hz, yang secara signifikan lebih tinggi daripada sinyal dari kelompok ikan berusia 13-15 bulan yaitu 692,8 Hz-688,2 Hz, dan kelompok ikan berusia 3 tahun yang berkisar $712,8 \mathrm{~Hz}$ 676,0 Hz (Wei Chong et al. 2016)
Relative amplitude suara ikan gulamah hasil penelitian berkisar antara $-75 \mathrm{~dB}$ hingga $-45 \mathrm{~dB}$, ditunjukkan pada Gambar 4 (sumbu y kanan) dan Gambar 5 (sumbu y/warna garis). Sedangkan untuk selang durasi suara rata-rata $130 \mathrm{~ms}$, nilai ini sedikit lebih besar dibandingkan dengan spesies Atlantic Croaker dalam beraktivitas sering mengeluarkan bunyi "knock" dengan selang durasi bunyi antara 88-106 $\mathrm{msec}$, durasi bunyi yang dihasilkan berkorelasi positif dengan kepadatan Atlantic Croaker (Damon 2007). Selang durasi antar suara ditunjukkan pada Gambar 6.

Data spektrum diatas, bisa dijadikan referensi pengembangan alat pemanggil ikan. Hal ini senada dengan pernyataan Winn (1991), bahwa suara merupakan hal yang sangat penting terhadap tingkah laku saat berkomunikasi untuk beberapa jenis ikan dan menurut Pratt (1998) ikan dapat mengeluarkan beragam amplitude suara untuk melakukan komunikasi dalam pertukaran informasi. Informasi yang dibawa dari sinyal-sinyal suara menjelaskan mengenai keadaan bahaya yang mengancam, keadaan agresif untuk menakuti musuh, 
atau panggilan peminangan. Suara juga dihasilkan dari dampak tingkah laku lainnya seperti saat makan, bergerak, menghindari musuh, dan reproduksi (seksualitas dan fase pembesaran) (Popper \& Plat 1993). Rosana et al. (2018), bahwa mayoritas ikan yang tertarik pada uji coba piknet di gillnet adalah dikisaran 500-1.500 $\mathrm{Hz}$. Berdasarkan pendapat tersebut, suara ikan berpotensi sebagai alat pengumpul dan dengan diketahuinya frekuensi dan amplitude suara gulamah memungkinkan pengembangan rumpon atau FAD (fish aggregating device) berbasis suara dengan sistem kerja memancarkan suara gulamah dengan frekuensi dan amplitude yang sama dalam air sehingga diharapkan bisa memikat gerombolan ikan gulamah.

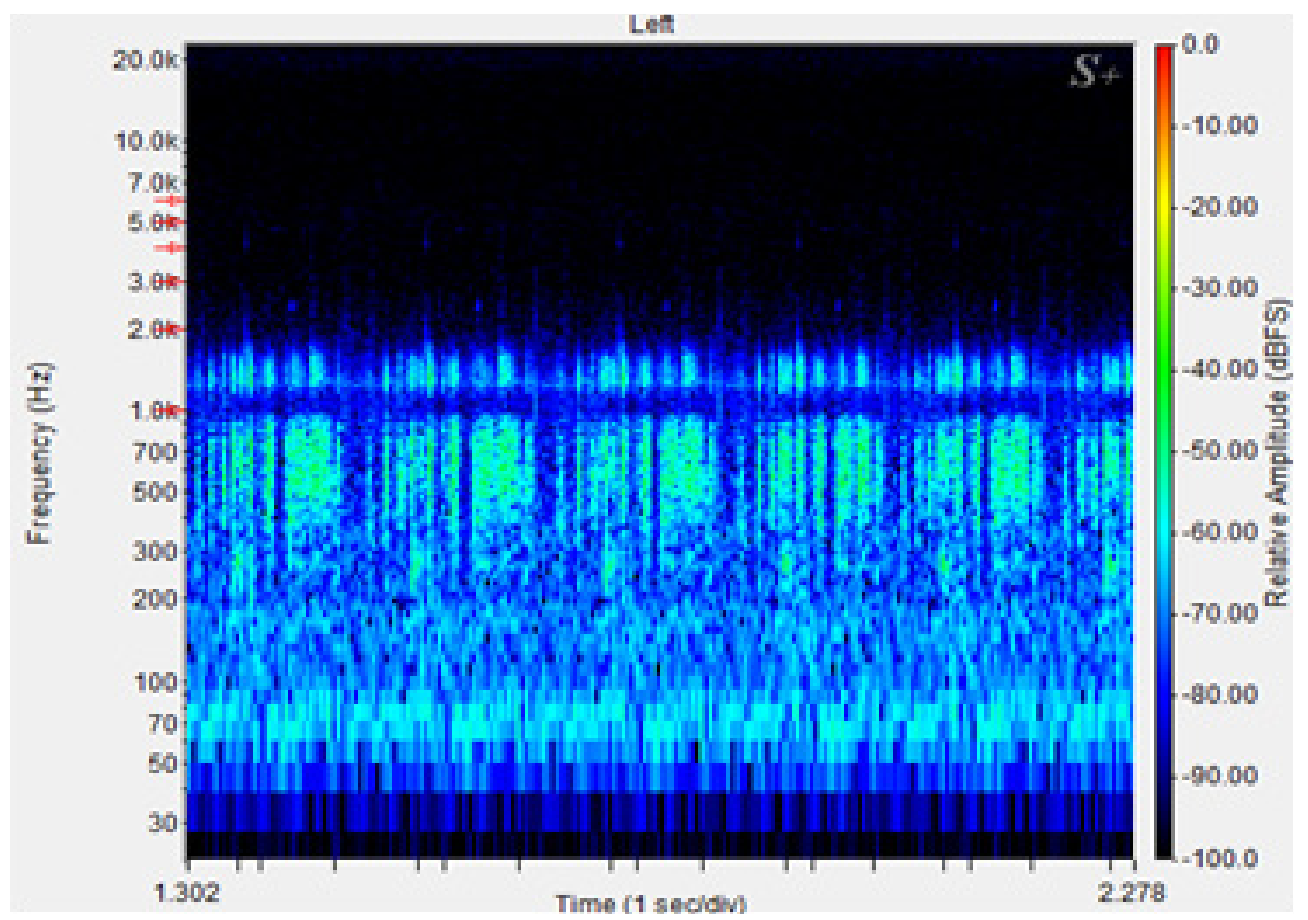

Gambar 4. Spektrogram hubungan frekuensi dan amplitudo suara ikan gulamah

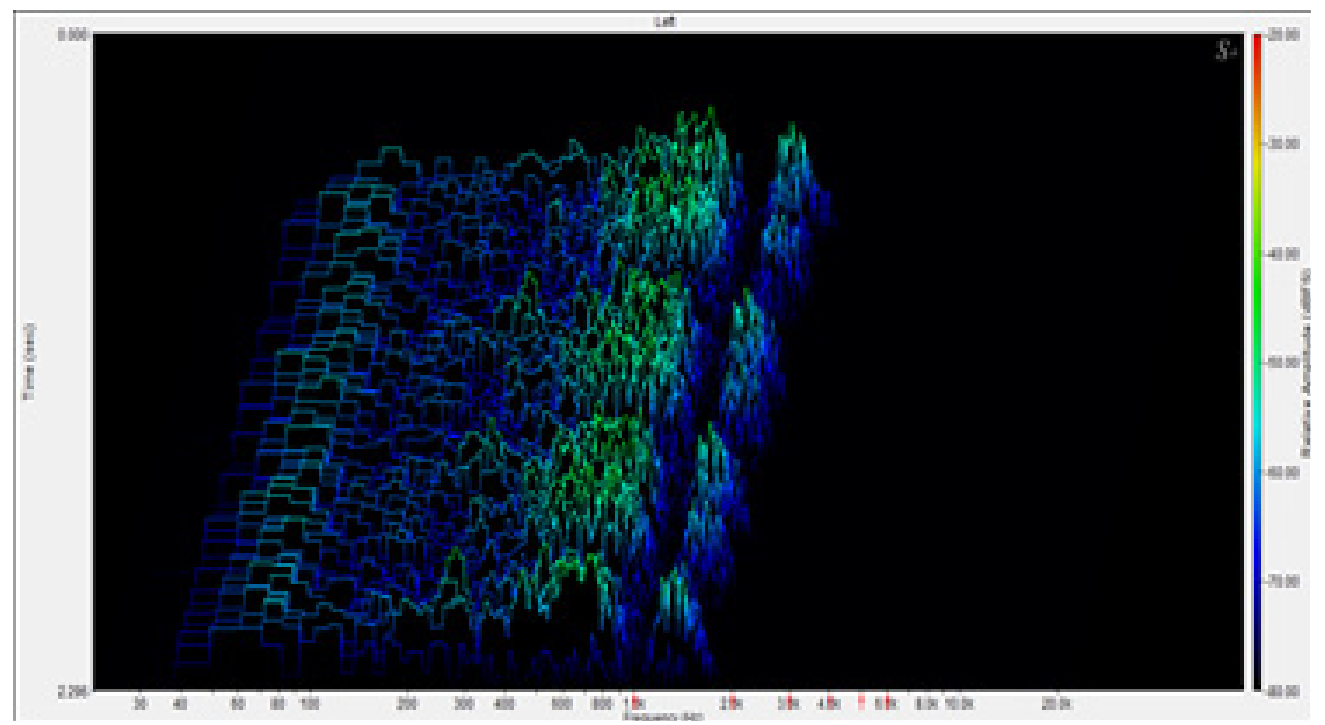

Gambar 5. Frekuensi dan amplitudo suara ikan gulamah 


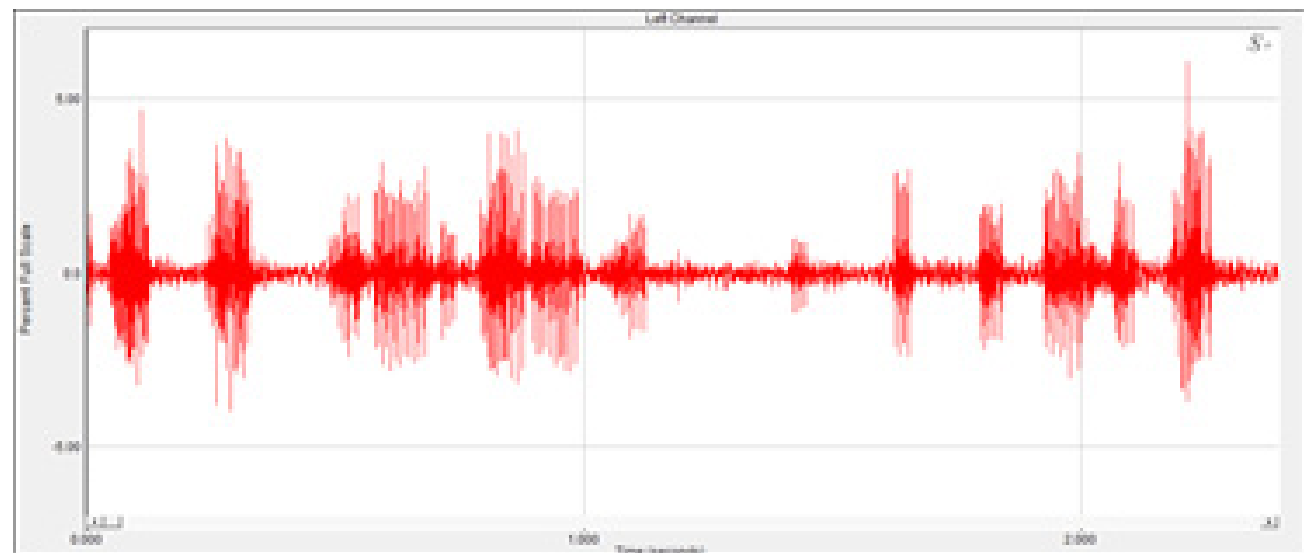

Gambar 6. Selang suara spektrum ikan gulamah satu dengan lainnya

\section{KESIMPULAN DAN SARAN}

\section{Kesimpulan}

Frekuensi suara schooling ikan gulamah (Johnius sp.) berkisar antara $37,83 \mathrm{~Hz}-1795$ $\mathrm{Hz}$ dengan peak frekuensi $732,13 \mathrm{~Hz}$ dengan relative amplitude berkisar antara $-75 \mathrm{~dB}$ hingga $-45 \mathrm{~dB}$. Nilai spektrum suara ini dapat digunakan sebagai basis data (audio) dalam pembuatan rumpon/fish aggregating device untuk mengumpulkan ikan gulamah dengan memancarkan suara gulamah tersebut ke dalam air. Dalam pengembangan rumpon berbasis suara (sound-fish aggregating device) khususnya untuk mengumpulkan gulamah sebaiknya menggunakan kisaran frekuensi tersebut.

\section{Saran}

Penelitian ini sebaiknya dilakukan pada lokasi-lokasi yang berbeda sehingga dapat merepresentasikan spektrum suara ikan gulamah (Scianidae) yang ada di Indonesia. Selain itu perlu adanya informasi yang lebih yaitu hubungan antara spektrum suara dengan ukuran mata gonad serta kelimpahan ikannya, sehingga dalam pengembangan sound-fish aggregating device dapat benar-benar ramah lingkungan dan bisa selektif terhadap ukuran ikan tertentu sesuai target tangkapan yang diinginkan. Oleh karena itu, perlu dilakukan penelitian menggunakan metode akustik pasif dan aktif sekaligus. Akustik pasif digunakan untuk merekam suara dan akusik pasif untuk mendeteksi kelimpahan schooling-nya.

\section{UCAPAN TERIMA KASIH}

Terimakasih penulis ucapkan kepada pihak Universitas Brawijaya yang sudah memberikan Hibah bagi peneliti pemula melalui LPPM-UB, selain itu juga dukungan dari Research Group IMFISHER, Fakultas Perikanan dan Ilmu Kelautan Universitas Brawijaya atas kesempatan yang diberikan untuk berkarya.

\section{DAFTAR PUSTAKA}

Damon P. Gannon. 2007. Acoustic Behavior of Atlantic Croaker, Micropogonias undulatus (Sciaenidae). Copeia, 2007(1) : 193-205.

Fish MP, Mowbray WH. 1970. Sounds of Western North Atlantic Fishes. Baltimore, MD: Johns Hopkins Press.

Hanna Y. 2017. Benang Jahit untuk Operasi Ternyata Berasal dari Ikan. http://bobo.grid.id/ read/08676051/benang-jahituntuk-operasi-ternyata-berasaldari-ikan?page $=$ all. $\quad$ [September 2018].

Imrantika F. 2018. Gelembung Renang Ikan Yang Bernilai Jual Jutaan. https:// farming.id/gelembungrenang-ikan-bernilai-jualjutaan/. [September 2018].

Johnston CE, Phillips CT. 2003. 
Sound Production in Sturgeon, Scaphirhynchus albus and S. Platorynchus (Acipenseridae). Environmental Biology of Fishes. 68 : 59-64.

Johnston CE, Vives SP. 2003. Sound Production in Codoma Ornata (Girard) (Cyprinidae). Environmental Biology of Fishes. 68 : 81-85.

Juanes F. 2002. Listening to Fish: an International Workshop on the Application of Passive Acoustics in Fisheries. Reviews in Fish Biology and Fisheries. $12: 105-106$.

Kaatz IM. 2002. Multiple Sound Producing Mechanism in Teleost Fishes and Hypotheses Regarding Their Behavioural Significance. Bioacoustics. 12 : 230-233.

Kottelat M, Whitten AJ, Kartikasari SN, Wirjoatmodjo S. 1993. Ikan Air Tawar Indonesia Bagian Barat dan Sulawesi. Periplus Editions Limited. Jakarta. 293 hal.

Lubis MZ, Wulandari PD, Pujiyati S. 2015. Bioakustik Suara Stridulatory Gerak Ikan Guppy (Poecilia Reticulata) pada Air Bersalinitas. Jurnal Teknologi Perikanan dan Kelautan. 6 (1) : 119127.

Lugli M, Yan HY, Fine ML. 2003. Acoustic Communication in Two Freshwater Gobies: the Relationship between Ambient Noise, Hearing Thresholds and Sound Spectrum. Journal of Comparative Phisiology.

Martin L, Amundsen L. 2011. Recent Advances in Technology: Fish Hear a Great Deal. Geo Expro: Geo Science Magazine. 8 (3) : 37-41.

Pitcher TJ.1993. Behaviour of Teleost Fishes. 2nd ed. Champan \& Hall. London. England.468 p.

Popper AN dan C Plat. 1993. Inner Ear and Lateral Line P. 116 - 117. In David H. Evans. (ed). The Physiology of Fishes. CRC Press. Boca Raton.

Pratt M. 1998. Better Angling With Simple Science: The White Friars Press. London.

Randhi Z, Hestirianoto T, Pujiyati S. 2017. Akustik Dibandingkan dengan Densitas Ikan: Kombinasi Metode Aktif dan Pasif. Jurnal Teknologi Perikanan dan Kelautan. 8 (2) : 187-
198.

Rosana N, Rifandi S. 2018. Rancang Bangun dan Uji Coba Alat Pemanggil Ikan "Piknet" untuk Alat Tangkap Jaring Insang. Marine Fisheries: Journal of Marine Fisheries Technology and Management. 9 (2) : 199-207.

Rountree RA, Gilmore RG, Goudey CA, Hawkins AD, Luczkovich JJ, Mann DA. 2006. Listening to Fish: Applications of Passive Acoustics to Fisheries Science. Fisheries. 31 (9) : 433-446.

Walker WF, Jr. 1997. Functional Anatomy of the Vertebrates. CBS College Publishing. United States America.

Wei Chong, Zhang Yu, Song Zhongchang. 2016. Acoustic Signal Characteristics of Net-Cage-Cultured Large Yellow Croakers, Pseudosciaena crocea. Jurnal Ilur Transactions on Science and Engineering, Volume 2016 (2016), Article ID 20160403.

Winn HE. 1991. Acoustic Discrimination By The Road FishWith Comments On Signal System. P 361 - 381. In Howard E. Winn. Dan Bori J. Olla. (ed) Behavior of Marine Animals Vol 2: Vertebrates. Plenum Press. New york.

Xin-min, GAO Da-zhi, YAO Yu-ling, YANG Feng, LIU Jia-fu, XIE Fang-jing. 2007. Occurrence and Characteristic of Sound in Large Yellow Croaker (Pseudosciaena crocea). Journal of Dalian Ocean University, 2007 volume 2 .

Yusfiandayani R, Amelia DR, Riyanto M. 2018. Produktivitas Rumpon Portable Menggunakan Pancing Ulur di Perairan Jepara. Jurnal Teknologi Perikanan dan Kelautan. 8 (2) : 179186.

Yusfiandayani R, Jaya I, Baskoro MS. 2014. Konstruksi dan Produktivitas Rumpon Portable di Perairan Palabuhanratu, Jawa Barat. Jurnal Teknologi Perikanan dan Kelautan. 5 (1) : 117-129.

Yusfiandayani R, Jaya I, Baswantara A. 2014. Electronic Fish Aggregating Device Operation On Lift Net in Lancang Island, Thousand Island, Jakarta. Jurnal Teknologi Perikanan dan Kelautan. 5(1) : 75-82. 